\title{
Mesospheric temperature inversions over the Indian tropical region
}

\author{
S. Fadnavis and G. Beig \\ Indian Institute of Tropical Meteorology, Dr. Homi Bhabha Road, 411008 Pashan Pune, India \\ Received: 19 December 2003 - Revised: 25 May 2004 - Accepted: 11 June 2004 - Published: 3 November 2004
}

\begin{abstract}
To study the mesospheric temperature inversion, daily temperature profiles obtained from the Halogen Occultation Experiment (HALOE) aboard the Upper Atmospheric Research Satellite (UARS) during the period 19912001 over the Indian tropical region $\left(0-30^{\circ} \mathrm{N}, 60-100^{\circ} \mathrm{E}\right)$ have been analyzed for the altitude range $34-86 \mathrm{~km}$. The frequency of occurrence of inversion is found to be $67 \%$ over this period, which shows a strong semiannual cycle, with a maximum occurring one month after equinoxes (May and November). Amplitude of inversion is found to be as high as $40 \mathrm{~K}$. Variation of monthly mean peak and bottom heights along with amplitude of inversions also show the semiannual cycle. The inversion layer is detected most frequently in the altitude range of $70-85 \mathrm{~km}$, with peak height ranging from 80 to $83 \mathrm{~km}$ and that of the bottom height from 72 to $74 \mathrm{~km}$. A comparison of frequency of temperature inversion with that obtained from Rayleigh lidar observations over Gadanki $\left(13.5^{\circ} \mathrm{N}, 60-100^{\circ} \mathrm{E}\right)$ is found to be reasonable. The seasonal variation of amplitude and frequency of occurrence of temperature inversion indicates a good correlation with seasonal variation of average ozone concentration over the altitude range of the inversion layer.
\end{abstract}

Key words. Atmospheric composition and structure (pressure, density and temperature) - Ionosphere (ionosphereatmosphere interactions; ionospheric disturbances)

\section{Introduction}

The "Thermal Inversion Layer" is a region of enhanced temperature within the upper mesosphere and is frequently observed and reported over the years with a variety of sensing instruments. These mesospheric inversion layers (MILs) were first reported by Schmidlin (1976) based on the falling sphere Rocket experiment. Chandra (1980) explained MILs by using a one-dimensional model. A number of later studies using different techniques viz. Rayleigh lidar (Hauchecorne et al., 1987; Jenkins et al., 1987; Meriwether et al., 1998; Thomas et al., 2001; Kumar et al., 2001), Sodium temperature lidar (States and Gardner, 1998; Chen et al., 2000; She et al., 1995), satellite photometry (Leblanc and Hauchecorne,

Correspondence to: S. Fadnavis

(suvarna@ tropmet.res.in)
1997; Clancy et al., 1989, 1994), etc., have repeatedly detected this mesospheric inversion layer phenomenon. Whiteway et al. (1995) reported that inversion layers are associated with an overlying, nearly adiabatic laps rate, which is an indication of a well mixed turbulent layer that is confirmed by a one-dimensional numerical model. Thomas et al. (1996) observed the mesospheric structures both above and below the temperature inversion. Later Thomas et al. (2001) observed MILs during both night and day, with a downward progression at $0.40 \pm 0.06 \mathrm{~km} / \mathrm{hr}$ with overlying adiabatic lapse rate. They correlated the amplitude of inversion with gravity wave activity. An average ( $24 \mathrm{~h}$ ) temperature profile shows no evidence of MILs. Sodium lidar measurements by States and Gardner (1998) during day and night have shown the relationship of MILs with tidal oscillations. She et al. (1993) and Bills et al. (1993) observed that the temperature of inversions is often included with long period wave activity through the mesopause region. Meriwether et al. (1994), using Rayleigh lidar observations, also observed similar wave activity with downward phase propagation for winter events. Their numerical, two-dimensional model of gravity wavetidal coupling points strongly to the conclusion that breaking gravity waves may play a significant role by amplifying the temperature amplitude of the tidal structure and production of large MILs (Liu et al., 1998, 1999, 2000). Recently, Meriwether et al. (2000) have given a thorough review of MILs and explained the possible causes for the occurrence of MILs. They reported that MILs are mostly noticed at two different altitude regions, $\sim 70 \mathrm{~km}$ (lower MILs) and $\sim 95 \mathrm{~km}$ (upper MILs). Lower MILs are observed by Rayleigh lidar and satellite measurements. Possible causes responsible for production of lower MILs are tidal, and gravity wave activity. Upper MILs ( $\sim 95 \mathrm{~km})$ observed from Sodium lidar measurments are linked to tidal activity and chemical heating (Dao et al., 1995; States and Gardner, 1998; 2000a, b; Berger et al., 1999). Meriwether and Mlynczak (1995) and Mlynczak et al. (1993) have suggested that the heating due to several exothermic chemical reactions (implying ozone) could promote temperature inversions. The majority of the studies give the characteristic of mesospheric inversion layer over the mid-latitudes. However, very few studies (Leblanc and Hauchecorne, 1997; Kumar et al., 2001; Nee et al., 2002) are over tropics. Kumar et al. (2001) studied MILs 
from Rayleigh lidar temperature data measured from March 1998 to February 2000 over Gadanki $\left(13.5^{\circ} \mathrm{N}, 79.2^{\circ} \mathrm{E}\right)$. The occurrence frequency of inversion showed semiannual variation with maxima in the equinoxes and minima in summer and winter. The magnitude of temperature deviation is around $20 \mathrm{~K}$ and its seasonal dependence follows an annual cycle (maximum in April and minimum in October). The peak of the inversion layer is found to be in the height range of 73-79 km and it follows an annual cycle with maximum in June and minimum in December. Recently, Kumar et al. (2003) compared Rayleigh lidar temperature profiles with HALOE temperature measurements over the same location at Gadanki. They reported that in the mesospheric inversion region of 70-80 km magnitude of temperature data obtained by lidar is about $5-10 \mathrm{~K}$ warmer than that of the HALOE data. Nee et al. (2002) presented atmospheric temperature profiles from lidar measurements over Taiwan $\left(25^{\circ} \mathrm{N}\right.$, $\left.121^{\circ} \mathrm{E}\right)$ and Gadanki $\left(13.5^{\circ} \mathrm{N}, 79.2^{\circ} \mathrm{E}\right)$ and compared them with HALOE profiles. They observed the presence of a mesospheric inversion layer in both lidar and HALOE profiles. Their Lidar profiles show the presence of MILs around $74 \mathrm{~km}$. Kumar et al. (2001) have also carried out MILs studies but only for shorter time series from a single location at Gadanki. However, study of MILs using HALOE data of 4 years in duration (11 October 1991 to 31 August 1995) is carried out by Leblanc et al. (1997). Amplitude of the inversions is calculated seasonally (three months average) for the seasons winter, spring, summer, autumn over the globe. Variation of the bottom altitude of temperature inversions with latitude is also studied. They have shown that the amplitude of inversion exhibits a semiannual cycle signature over lower latitudes. However, probably due to the limited number of data points, detailed work on the frequency of occurrence of the inversion layer, top and bottom altitudes of inversion, etc. has not been carried out so far using HALOE data. In the present work, detailed studies on this have been done using the monthly averages instead of seasonal averages. In addition to this, an attempt has been made to interpret the MILs by examining the correlation between the variation of monthly mean amplitude of temperature inversion and the monthly variation of averaged ozone $(70-86 \mathrm{~km})$. Present results are also compared with the results obtained by other workers over the Indian region.

\section{Data analysis}

HALOE experiment aboard the Upper Air Research Satellite (UARS) monitors vertical distribution of several minor constituents along with temperature (Marsh, 2000; Russell et al., 1993). The UARS orbit has an inclination of $57^{\circ}$ and a period of about 96 mins. This results in measurements of thirty profiles per day at two quasi-fixed latitudes, that is 15 at one latitude, corresponding to sunset and 15 at another one, corresponding to sunrise. The HALOE (version 19, Level 3AT) temperature data is for the period from October 1991 to September 2001, over the altitude range of $34-86 \mathrm{~km}$ with vertical resolution of about $2.3 \mathrm{~km}$, and this data have been analyzed in this study. The HALOE temperature data available during this period have been decoded and retrieved for the Indian tropical region $\left(0-30^{\circ} \mathrm{N}, 60-100^{\circ} \mathrm{E}\right)$. About 627 daily temperature profiles are thus available for this region. Error in the temperature runs from $1 \mathrm{~K}$ at $30 \mathrm{~km}$ to $20 \mathrm{~K}$ at $90 \mathrm{~km}$ (around $10 \mathrm{~K}$ at $75 \mathrm{~km}$ ). When daily temperature profiles from $34 \mathrm{~km}$ to $86 \mathrm{~km}$ were plotted, the most notable feature in the temperature structure of the mesosphere were the observed inversions. Standard vertical temperature profile shows decrease in temperature above the stratopause with an increase in altitude until the measopause above, which starts to increase with altitude. Figure 1 shows that temperature decreases above the stratopause are as usual but at about $75 \mathrm{~km}$ it starts to increase until $77-83 \mathrm{~km}$ and then it again decreases for some specific days known as inversion days. The altitude range $\sim 75-85 \mathrm{~km}$ in the mesosphere where temperature reversal takes place is known as the inversion layer. The difference between the maximum temperature and minimum temperature in this range is known as the amplitude of inversion layer. The altitude where temperature becomes minimum and then starts increasing is known as the bottom altitude of the inversion layer. The altitude where temperature becomes maximum and then again as usual starts decreasing is known as the top (peak) altitude of the inversion layer. The thickness is the difference between the altitude at the top and the altitude at the bottom of inversion layer. These altitudes, the thickness and the amplitude are noted for each day. Error in the temperature around the level of inversion is around $10 \mathrm{~K}$, hence only inversions of $10 \mathrm{~K}$ amplitude or more can be considered as significant.

The primary characteristic of an inversion layer is its amplitude. For a profile with no inversion, the amplitude is taken as zero. Amplitude, peak and bottom altitudes, and frequency of occurrence of the inversion layer are obtained on a daily basis. Monthly means are obtained by averaging them for the corresponding months over an entire 10-year period of measurement, to study their monthly and seasonal variations. Monthly mean amplitude of inversion is observed around $10 \mathrm{~K}$. Seasons are considered as November, December, January, February as winter, March, April as summer equinox, September, October as winter equinox and May, June, July, August as summer. Spectral analysis is carried out on the time series of 10 years for the monthly mean amplitude of the inversion layer to obtain the significant periodicities.

\section{Results and discussions}

Figure 1 shows the vertical temperature structure for the four randomly selected typical inversion days (17 May 1993, 6 October 1994, 5 November 1995, 26 October 1997). It demonstrates the variation in temperature and its reversal. In this figure, vertical temperature profiles are shifted by $40 \mathrm{~K}$. On 17 May 1993 a minimum temperature of $185.00 \mathrm{~K}$ is observed at an altitude of $72 \mathrm{~km}$ above which it does not follow 


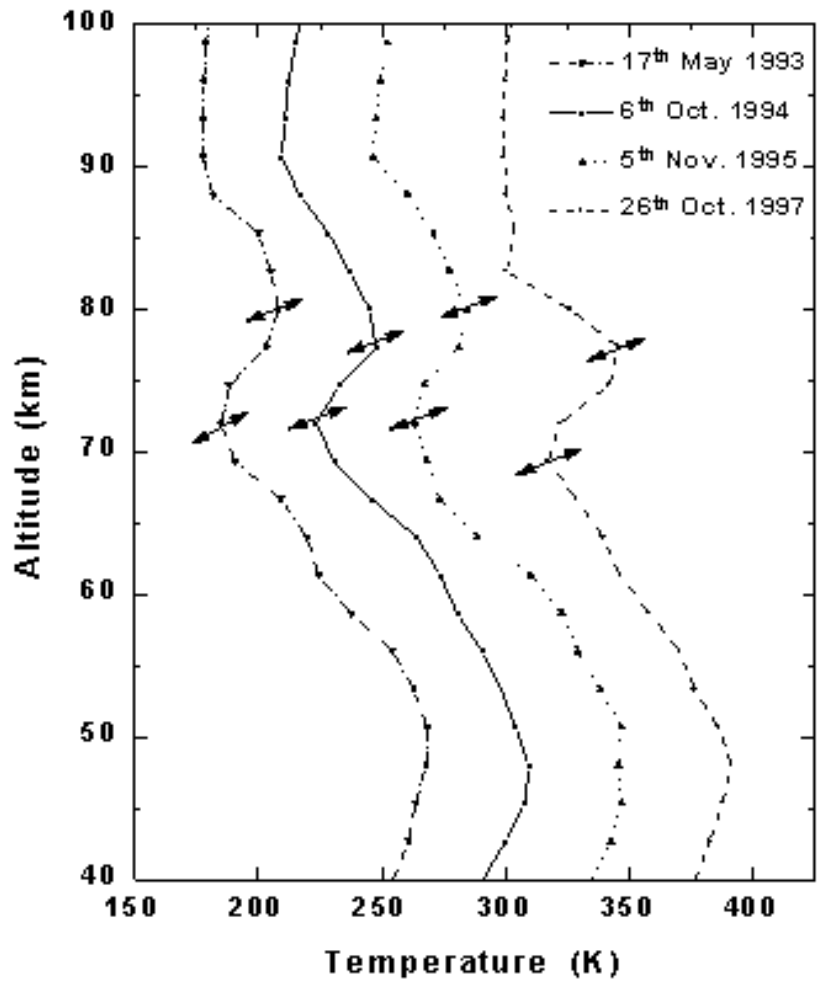

Fig. 1. Vertical temperature structure for the four randomly selected typical inversion days within the Indian tropical belt obtained by HALOE experiment (17 May 1993, 6 October 1994, 5 November 1995, 26 October 1997). Double-sided arrow represents width of inversion layer.

the usual fall in temperature as per the laps rate. Instead it increases with height and touches a maximum of $208.10 \mathrm{~K}$ at an altitude of $80 \mathrm{~km}$ above, which it again starts to decrease. The amplitude of inversion for this layer is found to be $23.10 \mathrm{~K}$. Similarly, the inversion layer can be seen in other profiles, which are marked as double-sided arrows in Fig. 1. In a similar manner, all the profiles are examined for the entire 10-year period and the amplitude, bottom altitude, peak altitude, and occurrence of the inversion layer are obtained for each day. Results indicate that the frequency of occurrence of temperature inversions over the Indian tropical region is found to be $67 \%$ during this period. Figure 2 shows the monthly variation of the $\%$ frequency of occurrence of inversions averaged over a 10-year period considering two cases, in the first case days with an amplitude of inversion greater than $5 \mathrm{~K}$ and in the second case days with an amplitude of inversion greater than $10 \mathrm{~K}$. Both plots indicate a signature of semiannual cycle with a maximum frequency of occurrence one month after the equinoxes, i.e. in the month of May, followed by a secondary peak in November. The minima occur in the months of July followed by January.

Leblanc et al. (1997) studied mesospheric temperature inversions using 3 data sets obtained from Rayleigh lidar $\left(44^{\circ} \mathrm{N}, 5^{\circ} \mathrm{E}\right)$, ISAMS (Improved Stratospheric And Mesospheric Sounder) and HALOE measurements over the low
Indian Tropical Region $\left(0-30^{\circ} \mathrm{W}, 60-100^{\circ} \mathrm{E}\right)$

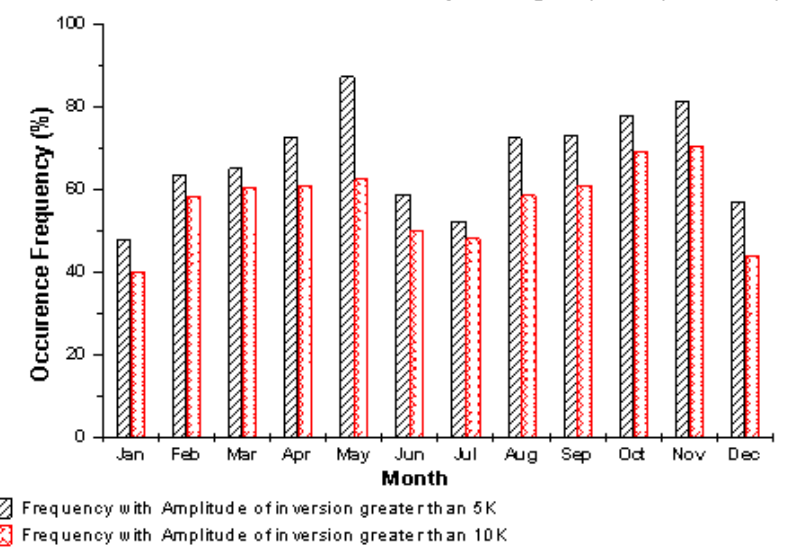

Fig. 2. Averaged monthly variation of the frequency of occurrence $(\%)$ as obtained in this work using the HALOE temperature series over the Indian tropical region $\left(0-30^{\circ} \mathrm{N}, 60-100^{\circ} \mathrm{E}\right)$ during the period 1991-2001. For the two cases 1) occurrence frequency calculated by considering the days with amplitude of inversion greater than $5 \mathrm{~K}$ and 2) occurrence frequency calculated by considering the days with amplitude of inversion greater than $10 \mathrm{~K}$.

and mid-latitude. They also found a semiannual cycle over low latitudes in these data sets with maxima one month after the equinoxes. However, the HALOE results obtained by them were based on only 4 years of data (October 1991 to August 1995). Kumar et al. (2001) studied mesospheric temperature inversions using Rayleigh lidar temperature measurements over low latitude $\left(13.5^{\circ} \mathrm{N}, 79.2^{\circ} \mathrm{E}\right)$ and observed a semiannual cycle in monthly variation of frequency of occurrence, which shows peaks during equinoxes. These results are found to agree well with our results.

The amplitude of temperature inversion appears to have strong variations. To study the seasonal variation we have averaged their amplitudes over months. The monthly mean amplitude of inversion over the entire period is presented in Fig. 3. Vertical bars show 2 sigma error at a $95 \%$ confidence level. It is clear from this figure that the monthly mean amplitude varies from $7 \mathrm{~K}$ to $12 \mathrm{~K}$. It shows a semiannual cycle with peaks in the months of May and October. The monthly mean amplitudes and occurrence frequency exhibit almost the same characteristic. This is also reported by other workers (Leblanc et al., 1995, 1997). The lidar and satellite observations reported by Leblanc et al. (1997) showed that amplitudes follow a semiannual cycle over low latitudes and an annual cycle at mid-latitudes. They reported a zonally a mean amplitude of 8-10 K near the equator and strong inversions at lower latitudes in early May, thus in agreement with our results. Mean amplitudes of $9.5 \mathrm{~K}$ during winter, $10 \mathrm{~K}$ during equinoxes and $8.6 \mathrm{~K}$ during summer are observed in the present analysis. Hauchecorne et al. (1991), Leblanc and Hauchecorne (1997) reported mean amplitude of $20 \mathrm{~K}$ during the winter months and between $5-10 \mathrm{~K}$ during the summer months over mid-latitudes. If we study the time evolution of the monthly mean amplitude of inversion, in the time series 


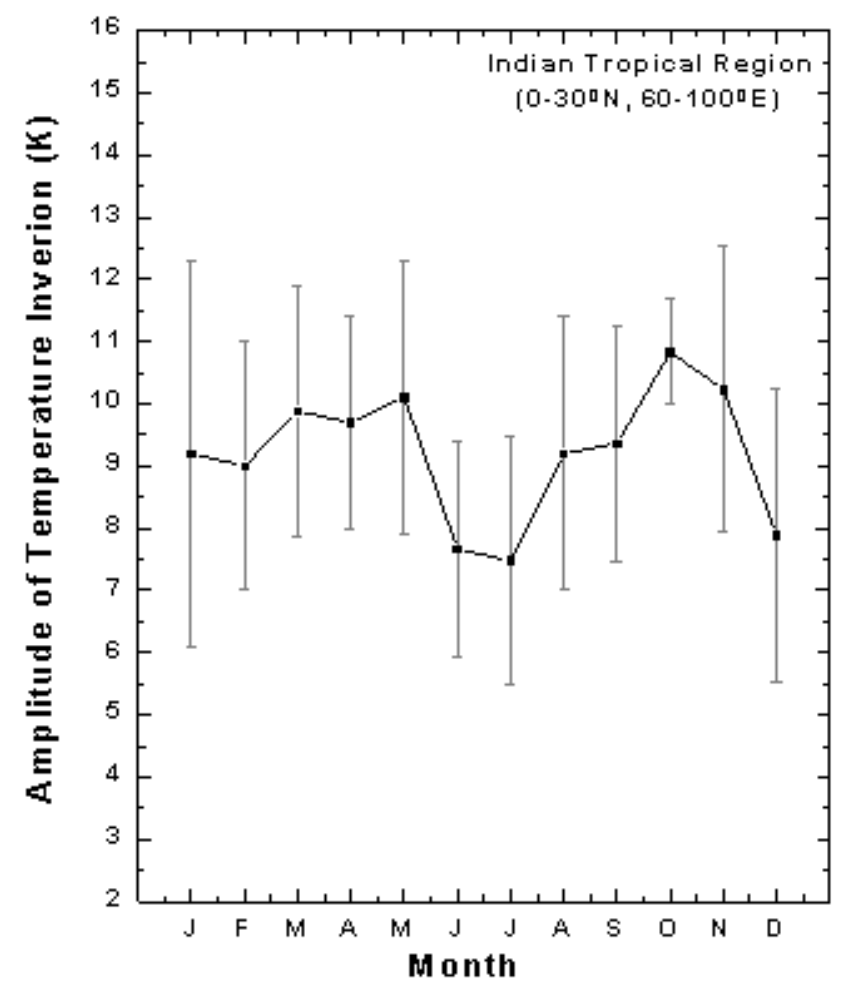

Fig. 3. Variation of monthly mean amplitude of temperature inversion (k) as obtained in this work using The HALOE temperature series over the Indian tropical region $\left(0-30^{\circ} \mathrm{N}, 60-100^{\circ} \mathrm{E}\right)$ during the period 1991-2001. Vertical bar represents 2 sigma error at $95 \%$ confidence level.

of 1991 to 2001, it is found that the amplitude of the inversion often reaches $14-15 \mathrm{~K}$. The amplitude measured for a given profile can easily reach $25-40 \mathrm{~K}$. Spectral analysis is also carried out on this time series of monthly mean amplitude which indicates a strong semiannual cycle. Semiannual oscillation is significant at a $95 \%$ confidence level. Vertical temperature gradient of $2-6 \mathrm{~K} / \mathrm{km}$ (occasionally $10 \mathrm{~K} / \mathrm{km}$ ) is observed on strong inversions days. Leblanc et al. (1997) have observed the mean vertical gradients of $3-5 \mathrm{~K} / \mathrm{km}$ in all the seasons.

Monthly mean peak altitude is obtained by averaging peak altitudes of inversions occurring in the corresponding month. Similarly monthly mean bottom altitude of inversions is obtained by averaging bottom altitudes of inversions. Monthly variations of peak and bottom altitudes of inversions are shown in Fig. 4. An inversion peak occurs between $80-83 \mathrm{~km}$ and the bottom altitude lies somewhere between $74-76 \mathrm{~km}$. It is clear from this figure that the peak and bottom altitudes follow each other from month to month and are observed to be high in the months of April and September. The time series of variation in the peak and bottom heights when plotted for the entire 10-year period indicate a semiannual oscillation as found in the amplitude and frequency of occurrence in temperature inversions. Leblanc et al. (1997), from satellite observations over low latitude, have observed the development

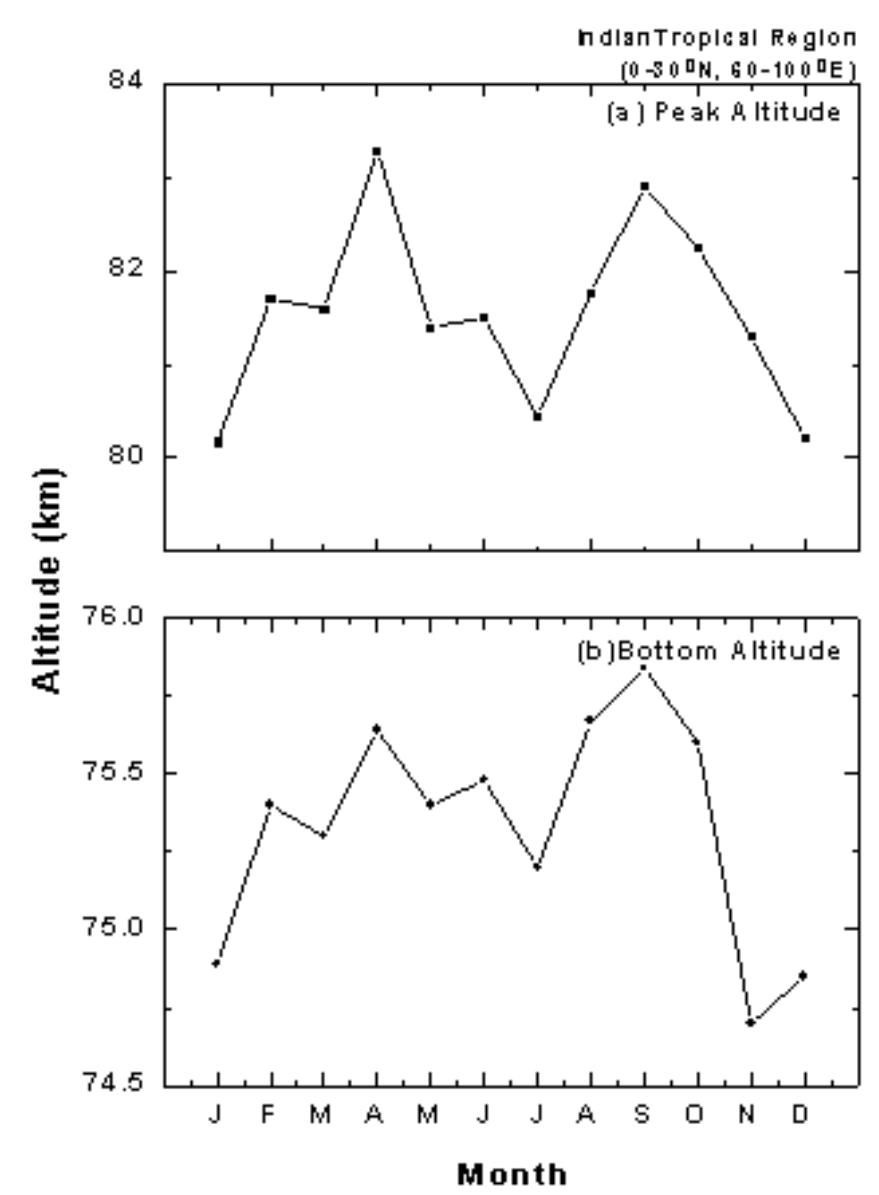

Fig. 4. Monthly variations of occurrence of (a) peak altitude and (b) bottom altitude of temperature inversions as obtained in this work using the HALOE temperature series over the Indian tropical region $\left(0-30^{\circ} \mathrm{N}, 60-100^{\circ} \mathrm{E}\right)$ during the period $1991-2001$.

of strong inversion over $80-85 \mathrm{~km}$, occurring a few weeks after the equinoxes, which is in agreement with our results. In the present work, the width of the inversion layer is found to be about $5-8 \mathrm{~km}$. It is broad $(\sim 7 \mathrm{~km})$ in the month of April and September. She et al. (1993), Senft et al. (1994), using Sodium lidar temperature observations reported, that for the seasons where the inversion layer was observed in average temperature data, the layer width of about $5 \mathrm{~km}$ is seen and the amplitude of the layer is typically 5 to $10 \mathrm{~K}$. However, the results of the above two authors pertain to mid-latitude, whereas the results of the present study relate to equatorial and the low mid-latitude region $\left(0-30^{\circ} \mathrm{N}\right)$. The characteristics and causes of mesospheric inversion could be different in the two regions.

In order to examine the low-latitude features and to compare the present results with that of Rayleigh lidar observations over Gadanki $\left(13.5^{\circ} \mathrm{N}, 79.2^{\circ} \mathrm{E}\right)$ India, reported by $\mathrm{Ku}-$ mar et al. (2001), we have analyzed the daily mean temperature profiles in a narrow belt over the Indian region $\left(0-15^{\circ} \mathrm{N}\right.$, $60-100^{\circ} \mathrm{E}$ ). To study monthly variation they are averaged over a month. Monthly variation of frequency of occurrence, 


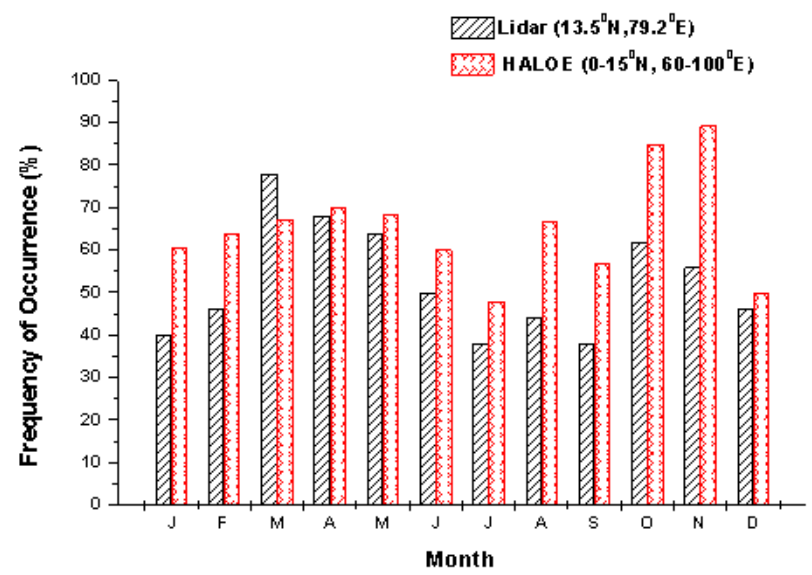

Fig. 5. Comparison in the monthly mean frequency of occurrence of temperature inversion (\%) obtained in this work using HALOE data over Indian region $\left(0-15^{\circ} \mathrm{N}, 60-100^{\circ} \mathrm{E}\right)$ and that of Kumar et al. (2001) obtained by lidar data at Gadanki $\left(13.5^{\circ} \mathrm{N}, 79.2^{\circ} \mathrm{E}\right)$ taken during the period 1998-2001.

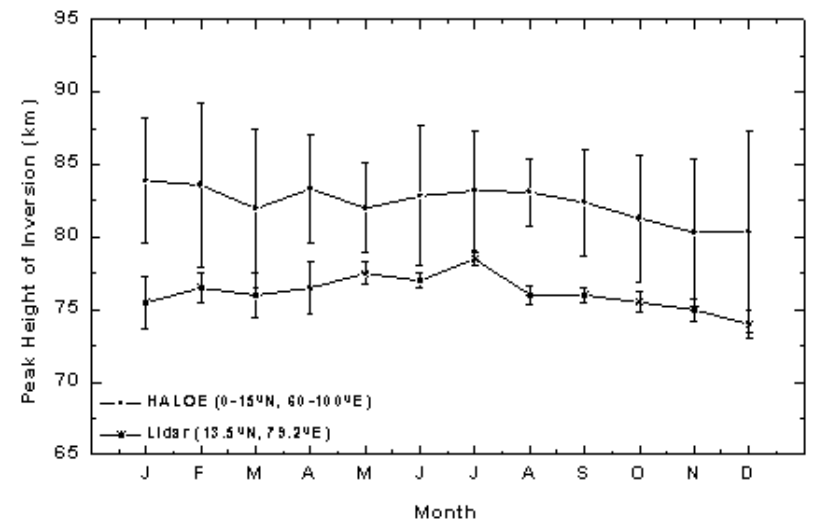

Fig. 6. Comparison in the monthly mean peak height of the inversion layer in $\mathrm{km}$ as obtained in this work using HALOE data over the Indian region $\left(0-15^{\circ} \mathrm{N}, 60-100^{\circ} \mathrm{E}\right)$ and that of Kumar et al. (2001) obtained by lidar data at Gadanki $\left(13.5^{\circ} \mathrm{N}, 79.2^{\circ} \mathrm{E}\right)$ taken during the period 1998-2001.

peak height variation and frequency of height of occurrence are compared. Kumar et al. (2001) studied characteristic of MILs from Rayleigh lidar data for 119 nights collected during a 2-year period (March 1998 to February 2001). Figure 5 shows the percentage frequency of occurrence over Gadanki as reported by Kumar et al. (2001) and that obtained in the present work $\left(0-15^{\circ} \mathrm{N}, 60-100^{\circ} \mathrm{E}\right)$. Both the results show signature of semiannual cycle. Peaks of semiannual cycle are observed during the month of March and October over Gadanki, whereas it is found in the months of April and November in the present work. Both primary and secondary peaks are shifted by one month in the present work. The value of the percentage frequency of occurrence is found to be higher in the present work as compared to the results reported by Kumar et al. (2001) over Gadanki (38-78\%). This is probably due to the fact that the present results cover the latitude bin $\left(0-15^{\circ} \mathrm{N}\right)$, whereas the results from Kumar et

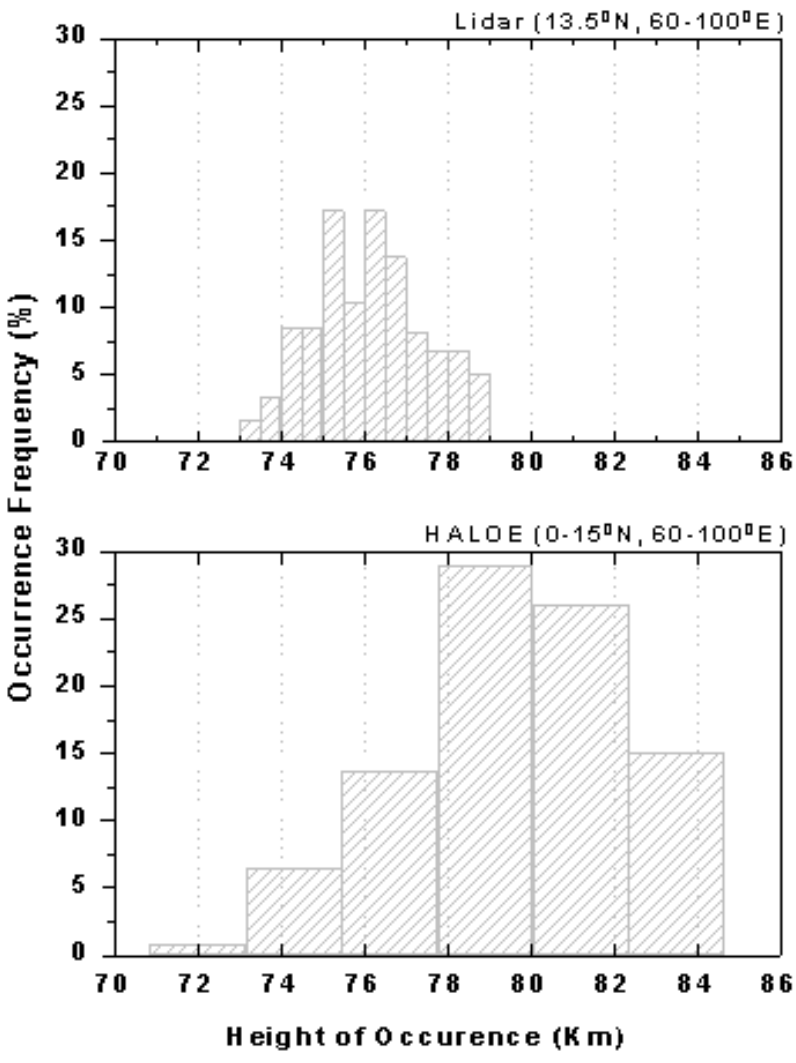

Fig. 7. Mesospheric temperature inversion frequency distribution for height of occurrence over (a) Gadanki $\left(13.5^{\circ} \mathrm{N}, 79.2^{\circ} \mathrm{E}\right)(\mathbf{b})$ present work $\left(0-15^{\circ} \mathrm{N}, 60-100^{\circ} \mathrm{E}\right)$.

al. (2001) results are for a specific station. In addition, the numbers of data points are also higher in the present work. The other reason for this difference may be that Lidar is a ground-based technique while HALOE is measuring temperature profiles from the top of the atmosphere. Alternatively, it may be argued that the frequency of occurrence is much higher than that of Lidar measurements in the months of October, November, December January and February. These are the months when southwest monsoon ends and the northeast monsoon sets over east coast of India, and as Lidar is a ground-based technique, clouding during these months may underestimate the Lidar temperature profiles. However, the main characteristics are almost similar in nature. Whiteway et al. (1995), using the Rayleigh lidar obervations, found the rate of occurrence to be $\sim 90 \%$ in the months of November to February, $\sim 20 \%$ during May and July and $40-60 \%$ during the other months at York

University $\left(44^{\circ} \mathrm{N}, 80^{\circ} \mathrm{W}\right)$. Figure 6 shows the monthly variation peak heights as obtained in the present work over Gadanki. Peak heights are confined to the altitude range of $73-79 \mathrm{~km}$ over Gadanki, whereas it is between $80-84 \mathrm{~km}$ in the present study. Figure 7 shows that maximum inversions occurred in the height range of 76-78 km over Gadanki, and $78-82 \mathrm{~km}$ over the present analysis of the low-latitude Indian region. Leblanc et al. (1997) also found the peak of the inversion layer to be around $\sim 75-85 \mathrm{~km}$ over low latitudes, 
Table 1. Exothermic reactions responsible for significant heating in the middle atmosphere.

\begin{tabular}{|c|c|c|c|}
\hline Sr. no. & Reaction & $\begin{array}{l}\text { Heat of Reaction } \\
\text { (Kcal/mole) }\end{array}$ & Comments \\
\hline $\mathrm{R} 1$ & $\mathrm{O}+\mathrm{OH} \Rightarrow \mathrm{O}_{2}+\mathrm{H}$ & -16.77 & $\begin{array}{l}\text { This is the least exothermic of all seven reactions } \\
\text { but is nonetheless a significant source of heat near } \\
\text { the mesopause region with a peaking heating rate } \\
\text { exceeding } 1.1 \mathrm{~K} / \mathrm{d} \text {. }\end{array}$ \\
\hline $\mathrm{R} 2$ & $\mathrm{H}+\mathrm{O}_{2}+\mathrm{M} \Rightarrow \mathrm{HO}_{2}+\mathrm{M}$ & -49.10 & $\begin{array}{l}\text { The recombination of atomic hydrogen and } \\
\text { molecular oxygen is a moderate source of heat in } \\
\text { the vicinity of } 80 \mathrm{~km} \text {. }\end{array}$ \\
\hline R3 & $\mathrm{H}+\mathrm{O}_{3} \Rightarrow \mathrm{OH}+\mathrm{O}_{2}$ & -79.90 & $\begin{array}{l}\text { It is highly exothermic and is potentially the single } \\
\text { largest source of heat near the mesospause. }\end{array}$ \\
\hline $\mathrm{R} 4$ & $\mathrm{O}+\mathrm{HO}_{2} \Rightarrow \mathrm{OH}+\mathrm{O}_{2}$ & -53.27 & It is moderately exothermic. \\
\hline $\mathrm{R} 5$ & $\mathrm{O}+\mathrm{O}_{2}+\mathrm{M} \Rightarrow \mathrm{O}_{3}+\mathrm{M}$ & -25.47 & $\begin{array}{l}\text { This reaction is a significant source of heat in the } \\
\text { stratosphere and mesosphere. }\end{array}$ \\
\hline R6 & $\mathrm{O}+\mathrm{O}+\mathrm{M} \Rightarrow \mathrm{O}_{2}+\mathrm{M}$ & -119.40 & $\begin{array}{l}\text { It is a significant source of heat near the } \\
\text { mesospause. }\end{array}$ \\
\hline R7 & $\mathrm{O}+\mathrm{O}_{3}+\mathrm{M} \Rightarrow \mathrm{O}_{2}+\mathrm{O}_{2}$ & -93.65 & $\begin{array}{l}\text { Highly exothermic, is only a minor source of heat } \\
\text { in the lower thermosphere, because there is little } \\
\text { ozone at these altitudes. }\end{array}$ \\
\hline
\end{tabular}

which is close to the present findings. The slight differences in heights may be due to the fact that the inversion layer obtained from HALOE measurements is likely to be shifted due to smoothening. In addition to this, the vertical resolution in the present data is $\sim 2.3 \mathrm{~km}$ which is broad and may introduce some uncertainty. In general, several features are found to be similar in nature in the present analysis with that of Kumar et al. (2001). However, some obvious differences in the magnitude and height are noticed. One of the reasons could be that the present HALOE analysis is carried out for a latitude bin of $0-15^{\circ} \mathrm{N}$, whereas the analysis of Kumar et al. (2001) is for a single station, as mentioned earlier. Another reason may be that lidar temperatures are $\sim 5-10 \mathrm{~K}$ warmer than those of HALOE in the altitude range 70-80 km (Kumar et al., 2003; Leblanc et al., 1995, 1997).

\section{Interpretations}

There could be several reasons for the development of MILs. At present, it is not understood fully, in spite of the many studies being carried out. Possible physical mechanisms proposed for the production of MIL's structure are diverse. Several interpretations and processes, like chemical heating (implying ozone) (Meriwether et al., 1995; Mlynczak et al., 1991, 1993), dynamical interaction between gravity and/or tidal wave (Yu et al., 1997; Liu et al., 1999, 2000; Thomas et al., 2001) were proposed in the past. Mlynczak et al. (1991, 1993) and Meriwether et al. (1995) have reported that heating that occurs in the middle atmosphere is due to four (R1, $\mathrm{R} 2, \mathrm{R} 3, \mathrm{R} 4)$ exothermic reactions given in Table 1 .

Reactions R3, R5, R6 (given in Table 1), involving ozone and atomic hydrogen, contribute more in production of heat in the upper mesospheric region (above $60 \mathrm{~km}$ ). The reactions R4, R7 also make a contribution to the heat budget of the mesosphere (Mlynczak et al., 1993). To study the relationship of the inversion layer with variation in ozone concentrations, the HALOE 3AT (version 19) ozone measurements for the period 1991-2001 are archived over the same Indian tropical region $\left(0-30^{\circ} \mathrm{N}, 60-100^{\circ} \mathrm{E}\right)$. In the previous section, it is found that temperature inversion occurs mostly in the height range of $70-86 \mathrm{Km}$, therefore ozone concentrations are averaged over the similar altitude range of 70 to $86 \mathrm{~km}$. Monthly mean ozone profiles are obtained by averaging ozone concentrations for the corresponding months over the entire 10-year period. Figure 8 a shows the monthly variation of averaged ozone concentration and the amplitude of temperature inversions. It can be seen from this figure that the nature of variation in these two plots is almost identical, which implies some deep- association. To study this aspect in detail, a correlation coefficient between these two parameters is calculated. Amplitude of temperature inversion shows good correlation $(+0.65)$ with average ozone concentration. From Fig. 8a it is evident that when ozone concentrations are high, amplitudes of inversion are also high or when ozone concentrations are low, amplitudes of inversion are also low. This may be attributed due to variations in ozone concentration itself, which may vary the magnitude of chemical heating due to ozone. This may change the magnitude of temperature inversion, or there are many different mechanisms that could lead to in-phase ozone and temperature fluctuations, one of them being the MLT tides, another being fast lateral advection by high meridional winds. Batista et al. (1996) have reported that, over the equatorial 

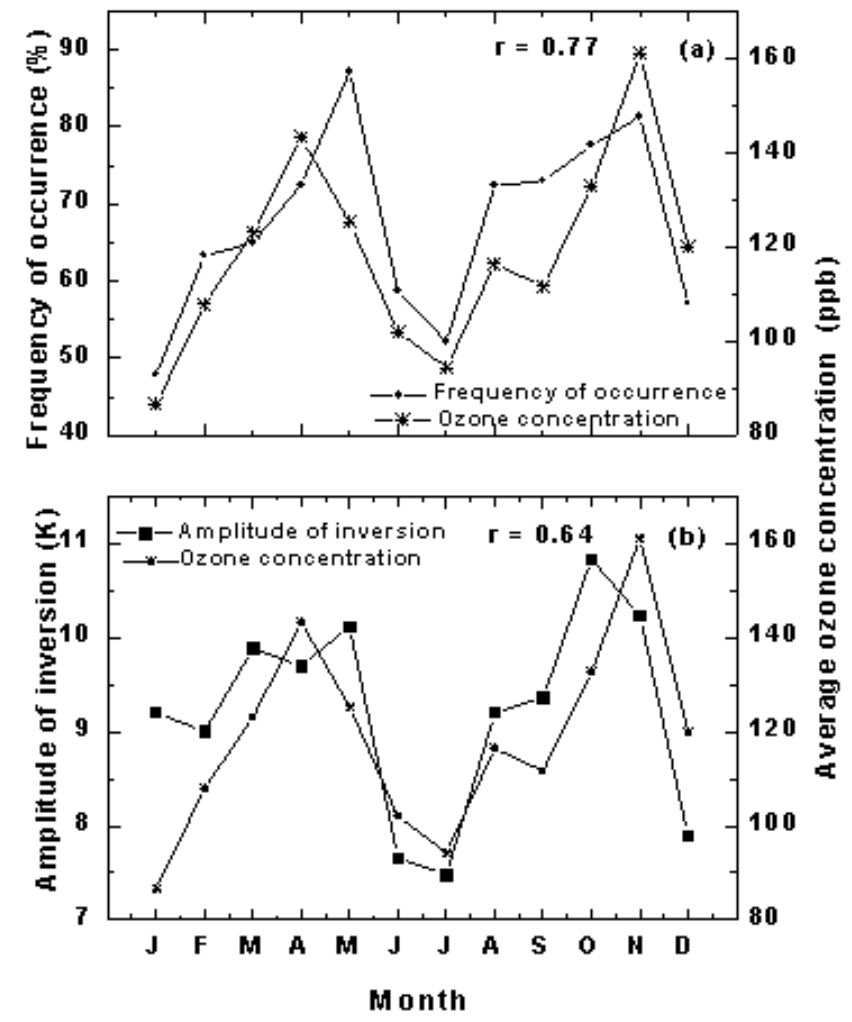

Fig. 8. Monthly mean variation in the (a) frequency of occurrence of temperature inversion (\%) and that of ozone volume mixing ratios (ppb), averaged over the altitude range of $70-86 \mathrm{~km}$. A correlation coefficient in these parameters is found to be +0.77 . (b) Amplitude of temperature inversion $(\mathrm{k})$ and that of ozone volume mixing ratios (ppb), averaged over the altitude range of $70-86 \mathrm{~km}$. A correlation coefficient in these parameters is found to be +0.64 . Both ozone volume mixing ratio and temperature data are obtained using HALOE during 1991-2001 over the Indian tropical region $\left(0-30^{\circ} \mathrm{N}, 60-100^{\circ} \mathrm{E}\right)$.

location, ozone concentration is minimum near $77 \mathrm{~km}$ and maximum near $82 \mathrm{~km}$. It is observed in this work that over the Indian tropical region, the bottom of the temperature inversion layer is near $75 \mathrm{~km}$ and the peak of the temperature inversion layer is $82 \mathrm{~km}$. Figure $8 \mathrm{~b}$ shows the monthly variation of average ozone concentrations and the \% frequency of occurrence of the temperature inversion layer. Percentage frequency of occurrence of temperature inversion shows good correlation with average ozone concentration, with the correlation coefficient being around +0.77 . Both frequency of occurrence and amplitude of inversion exhibit semiannual oscillation, which is also observed in averaged ozone concentrations $(70-86 \mathrm{~km})$. Other workers (Richard et al., 1990; Thomas et al., 1990), using satellite data, also found semiannual oscillation in ozone for the altitude range 70$90 \mathrm{~km}$, over the tropical region. Thomas et al. (1984) found a large seasonal variation in ozone near $\sim 80 \mathrm{~km}$. Ozone densities are double near equinoxes than near solstice, and the same feature is found in average ozone, as shown in Fig. 8a. Thomas et al. (1984) have proposed that the seasonal vari- ability in ozone is produced by the variation of gravity wave induced transport in the mesosphere, which, in turn, results from seasonal modulation of the propagation and breaking of small-scale gravity waves. Hauchecorne et al. (1987), Senft and Gardner (1991), Collins et al. (1994), Meriwether et al. (1994, 1998), Whiteway et al. (1995) have a related mechanism for the production of the inversion layer to the propagation of gravity waves. Therefore, it may be speculated that the combined effect of chemical heating (implying ozone) and gravity/tidal wave activity due to seasonal variability in the ozone may be considered as some of the important factors which may produce the inversion layer.

\section{Conclusion}

The HALOE temperature profiles over the Indian tropical region have shown the existence of the temperature inversion layer during the past 10 years. Inversions mostly occurred in the height range of 74-85 km with an amplitude of the order of $\sim 40 \mathrm{~K}$ locally and $\sim 10-14 \mathrm{~K}$ on monthly means. A semiannual cycle is observed in monthly variation of $\%$ frequency of occurrence, amplitude, peak and bottom altitudes of inversions. Percentage frequency of occurrence showed maxima one month after equinoxes, whereas for amplitude, peak and bottom altitudes maximum occurred during equinoxes. The present results are found to be broadly in agreement with that of Rayleigh lidar data taken over the low-latitude station Gadanki, with analyzed latitude bin. The correlation coefficient and similarities in the nature of variations between the average ozone concentrations and amplitude of temperature inversion is found to be good. Hence, it is emphasized that the variation in ozone is one of the potential reasons of MILs.

Acknowledgements. The authors express gratitude to G. B. Pant for their encouragement during the course of this study.

Topical Editor U.-P. Hoppe thanks C. S. Gardner and another referee for their help in evaluating this paper.

\section{References}

Batista, P. P., Takahashi, H., Clemesha, B. R., and Llewellyn, E. J.: Mesospheric Ozone Concentration at Equatorial Latitude from the 1.27 u O2 Airglow Emission, J. Geophys. Res., 101, 79177921, 1996.

Berger, U. and Zahn, U. V.: The two level structure of the mesopause: A model study, J. Geophys. Res., 104, 22083 22 093, 1999.

Bills, R. E. and Gardner, C. S.: Lidar observations of the mesopause region temperature structure at Urbana, J. Geophys. Res., 98, 1011-1021, 1993.

Chandra, S.: Energetics and thermal structure of the middle atmosphere, Planet Space Science, 28, 585-593, 1980.

Chen, S., Zhilin, H., White, M. A., Chen, H., Krueger, D. A., and She, C. Y.: Lidar observations of seasonal variation of diurnal mean temperature in the mesopause region over Fort Collins, Colorado $\left(41^{\circ} \mathrm{N}, 105^{\circ} \mathrm{W}\right)$. J. Geophys. Res., 105, $12371-$ $12380,2000$. 
Clancy, R. T. and Rush, D. W.: Climatology and trends of mesospheric (58-90) temperatures based upon 1982-1986 SME limb scattering profiles, J. Geophys. Res., 94, 3377-3393, 1989.

Clancy, R. T., Rush, D. W., and Callan, M. T.: Temperature minima in the average thermal structure of the middle atmosphere (70$80 \mathrm{~km}$ ) from analysis of 40 to $92 \mathrm{~km}$ SME global temperature profiles, J. Geophys. Res. 99, 19001-19 020, 1994.

Collins, R. L., Nomura, A., and Gardner, C. S.: Gravity waves in the upper mesosphere over Antarctica: Lidar observations at the south pole and Syowa, J. Geophys. Res., 99, 5475-5485, 1994.

Dao, P. D., Farley, R., Tao, X., and Gardner, C. S.: Lidar observations of the temperature profile between 25 and $103 \mathrm{~km}$ : Evidence of tidal perturbation, Geophys. Res. Lett., 22, 2825-2828, 1995.

Jenkins, D. B., Wareing, D. P., Thomas, L., and Vaughan, G.: Upper stratospheric and mesospheric temperatures derived from lidar observations at Aberystwyth, J. Atmos. S.-P., 49, 287-298, 1987.

Kumar, V. S., Kumar, Y. B., Raghunath, K., Rao, P. B., Krishnaiah, M., Mizutani, K., Aoki, A., Yasui, M., and Itabe, T.: Lidar measurements of mesospheric temperature inversion at a low latitude, Ann. Geophys., 19, 1039-1044, 2001.

Kumar, V. S., Rao, P. B., and Krishnaiah, M.: Lidar measurements of stratosphere-mesosphere thermal structure at a low latitude:comparison with satellite data and models, J. Geophy. Res., 108, 4342-4352, 2003.

Leblanc, T. and Hauchecorne, A.: Recent observations of mesospheric temperature inversions, Geophys. Res. Lett., 102, 19471-19482, 1997.

Leblanc, T., Hauchecorne, A., Chanin, M. L. Taylor, F. W., Rodgers, C. D., and Livesey, N.: Mesospheric inversions as seen by ISAMS (UARS), Geophy. Res. Let., 22, 1485-1488, 1995.

Liu, H. L. and Hagan, M. E.: Local heating/cooling of the mesosphere due to gravity wave and tidal coupling, Geophys. Res. Lett., 25, 941-944, 1998.

Liu, H. L., Hays, P. B., and Robble, R. G.: A numerical study of gravity wave breaking and impacts on turbulence and mean state, J. Atmos. Sci., 56, 2152-2177, 1999.

Liu, H. L., Hagan, M. E., and Roble, R. G.: Local mean state changes due to gravity wave breaking modulated by the diurnal tide, J. Geophys. Res., 105, 12 381-12 396, 2000.

Hauchecorne, A., Chanin, M. L., and Wilson, R.: Mesospheric temperature inversion and gravity wave breaking. Geophys. Res. Lett., 14, 933-936, 1987.

Hauchecorne, A., Chanin, M. L., and Kechkut, P.: Climatology and trends of the middle atmospheric temperature $(33-87 \mathrm{~km})$ as seen by Rayleigh lidar over the south of Frence, J. Geophy. Res., 96, 15 297-15 309, 1991.

Marsh, D. R. and Russell III, J. M.: A tidal explanation for the sunrise/sunset in HALOE low-latitude nitric oxide obsevations, Geophys. Res. Lett., 27, 3197-3200, 2000.

Meriwether, J. W., Dao, P. D., McNutt, R. T., Klemetti, W., Moskowitz, W., and Dvidson, G.: Rayleigh lidar observations of mesosphere temperature structure, J. Geophys. Res., 99, 16973 16987, 1994.

Meriwether, J. W. and Mlynczak, M. G.: Is chemical heating a major cause of the mesosphere inversion layer? J. Geophys. Res., 100, 1379-1387, 1995.

Meriwether, J. W., Gao, X., Wickwar, V., Wilksrson, T., Beissner, K., Collins, S., and Hagan, M.: Observed coupling of the mesospheric inversion layer to the thermal tidal structure, Geophys. Res. Lett., 25, 1479-1482, 1998.

Meriwether, J. W. and Gardner, C. S.: A review of the mesospheric inversion layer phenomenon, J. Geophys. Res., 105, 12405 12 416, 2000.

Mlynczak, M. G. and Solomon, S.: Middle atmosphere heating by exothermic chemical reactions involving odd hydrogen species, Geophys. Res. Lett., 18, 37-40, 1991.

Mlynczak, M. G. and Solomon, S.: A detailed evaluation of the heating efficiency in the middle atmosphere, J. Geophys. Res. 98, 10 517-10 541, 1993.

Nee, J. B., Thulasiram, S., Chen, W. N., Ratnam, M. V., and Rao, D. N.: Middle atmospheric temperature structure over two tropical locations, Chung $\mathrm{Li}\left(25^{\circ} \mathrm{N}, 121^{\circ} \mathrm{E}\right)$ and Gadanki $\left(13.5^{\circ} \mathrm{N}\right.$, 79.2 ${ }^{\circ}$ E), J. Atmos. S.-P., 64, 1311-1319, 2002.

Richard, M. B., Strobel, D. F., Summers, M. E., Olivero, J. J., and Allen, M.: The seasonal variation of water vapour and ozone in the upper mesosphere: Implication for vertical transport and ozone photochemistry, J. Geophys. Res. 95, 883-893, 1990.

Russell, J. M., Lerry, L., Gordley, Park, J. H., Drayson, S. R., Hesketh, W. D., Ralph, J. C., Tuck, A. F., Frederick, J. E., Harries, J. E., and Crutzen P. J.: The Halogen occultation Experiment, J. Geophys. Res., 98, 10777-10 797, 1993.

Schmidlin, F. J.: Temperature inversions near 75 km, Geophys. Res. Lett., 3173-3176, 1976.

Senft, D. C., Papen, G. C., Gardner, C. S., Yu, J. R., Krueger, D. A., and She, C. Y.: Seasonal variations of the thermal structure of the mesopause region at Urbana, Illinois $\left(40^{\circ} \mathrm{N}, 88^{\circ} \mathrm{W}\right)$ and Fort Collins, Colorado ( $\left.41^{\circ} \mathrm{N}, 105^{\circ} \mathrm{W}\right)$, Geophys. Res. Lett., 21 , 821-824, 1994.

She, C. Y., Yu, J. R., and Chen, H.: Observed thermal structure of a midlatitude mesopause, Geophys. Res. Lett., 20, 567-570, 1993.

She, C. Y., Krueger, D. A., Roble, R., Keckhut, P., Hauchecorne, A., and Chanin, M. L.:: Vertical structure of midlatitude temperature from stratosphere to mesosphere (30-105 km), Geophys. Res. Lett., 22, 377-380, 1995.

States, R. J. and Gardner, C. S.: Influence of the diurnal tide and thermospheric heat sources on the formation of mesospheric temperature inversion layers, Geophys. Res. Lett., 25, 1483, 1998.

States, R. J. and Gardner, C. S.: Thermal Structure of the mesopause region $(80-105 \mathrm{~km})$ at $40^{\circ} \mathrm{N}$ latitude, 1 . Seasonal variations, J. Atmos. Sci., 57, 66-77, 2000a.

States, R. J. and Gardner, C. S.: Thermal structure of the mesopause region $(80-105 \mathrm{~km})$ at $40^{\circ} \mathrm{N}$ latitude, 2. Diurnal variations, J. Atmos. Sci., 57, 78-92, 2000b.

Thomas, R. J. and Barth, C. A.: Seasonal variation of ozone in the upper mesosphere and gravity waves, Geophys. Res. Lett., 11, 673-676, 1984.

Thomas, R. J.: Seasonal Ozone Variations in the Upper Mesosphere, J. Geophys. Res., 95, 7395-7401, 1990.

Thomas, L., Marsh, A. K. P., Wareing, D. P., Astin, I., and Changra, H.: VHF echoes from the middle mesosphere and the thermal structure observed by lidar, J. Geophys. Res., 101, $12867-$ $12877,1996$.

Thomas, J. D., Sipler, D. P., and Salah, J. E.: Rayleigh lidar observations of a mesospheric inversion layer during night and day, Geophys. Res. Lett., 28, 3597-3600, 2001.

Whiteway, J., Carlswell, A. I., and Ward, W. E.: Mesospheric temperature inversions with overlying nearly adiabatic lapse rate: An indication of well mixed turbulent layer, Geophys. Res. Lett., 22, 1201-1204, 1995.

Yu, J. R., States, R. J., Franke, S. J., Gardner, C. S., and Hagan, M. E.: Observations of tidal temperature and wind perturbations in the mesopause region above Urbana, IL $\left(40^{\circ} \mathrm{N}, 88^{\circ} \mathrm{W}\right)$, Geophys. Res. Lett., 24, 1207-1210, 1997. 